\title{
Regulation of Fetoplacental Vascular Bed by Hypoxia
}

\author{
V. HAMPL ${ }^{1,2}$, V. JAKOUBEK ${ }^{1,2}$ \\ ${ }^{1}$ Center for Cardiovascular Research, ${ }^{2}$ Department of Physiology, Second Medical School, Charles \\ University, Prague, Czech Republic
}

Received October 5, 2009

Accepted October 30, 2009

\begin{abstract}
Summary
Important fetal and perinatal pathologies, especially intrauterine growth restriction (IUGR), are thought to stem from placental hypoxia-induced vasoconstriction of the fetoplacental vessels, leading to placental hypoperfusion and thus fetal undernutrition. However, the effects of hypoxia on the fetoplacental vessels have been surprisingly little studied. We review here available experimental data on acute hypoxic fetoplacental vasoconstriction (HFPV) and on chronic hypoxic elevation of fetoplacental vascular resistance. The mechanism of HFPV includes hypoxic inhibition of potassium channels in the plasma membrane of fetoplacental vascular smooth muscle and consequent membrane depolarization that activates voltage gated calcium channels. This in turn causes calcium influx and contractile apparatus activation. The mechanism of chronic hypoxic elevation of fetoplacental vascular resistance is virtually unknown except of signs of the involvement of morphological remodeling.
\end{abstract}

\section{Key words}

Placenta - Hypoxia - Intrauterine growth restriction • Vasoconstriction • Ion channels

\section{Corresponding author}

Václav Hampl, Professor of Physiology, Department of Physiology, Second Medical School, Charles University in Prague, Plzenská 130/221, 15000 Prague 5 - Motol, Czech Republic.

\section{Introduction}

The placenta is a crucial organ for the fetus, combining the function of several essential postnatal organ systems (lung, kidney, alimentary tract, endocrine functions, ...). Consequently, defects of the placental function are important causes of fetal and neonatal morbidity and mortality. It is thus not surprising that the transport function of the maternal-fetal interface in the placenta has been extensively studied for decades (Štulc et al. 1990, Pavek et al. 2003, Staud et al. 2006). Likewise, another important factor in the utero-placental function, namely the maternal perfusion of the uterine vessels under various conditions, is also quite well understood (Moore 2003, Osol and Mandala 2009). On the other hand, another important aspect of placental function - fetal perfusion of the placenta and its regulation - has been receiving relatively little attention.

One of the quite common conditions that are challenging to the developing fetus is placental hypoxia. It could result from maternal hypoxemia (e.g. during exposure to high altitude or due to maternal cardiovascular or respiratory diseases) or from impaired uterine blood flow (e.g. maternal hypertension or diabetes and especially preeclampsia). Regardless of its cause, placental hypoxia is commonly assumed to be an important factor in the development of serious fetal and perinatal disorders, especially intrauterine growth restriction (IUGR). By reducing fetoplacental blood flow, hypoxia is thought to cause fetal undernutrition and thus impairs fetal growth. IUGR is one of the most serious problems of current neonatology. With incidence of $5-7 \%$, it is a frequent cause of neonatal morbidity and increases the risk of disorders such as hypertension or diabetes in adulthood (Brodsky and Christou 2004). Umbilical artery Doppler ultrasound flow-velocity measurements indicate increased fetoplacental vascular impedance in IUGR (Arbeille 1997, Zamudio 2003). Nevertheless, the effects of hypoxia on fetoplacental 
vasculature are little studied.

This brief review therefore aims to summarize what is currently known about the regulation of already established fetoplacental vascular bed under the conditions of acute and chronic hypoxia. The review intentionally omits data about the effects of hypoxia on creation of placental vasculature and trophoblast invasion. These important topics are reviewed elsewhere (Straszewski-Chavez et al. 2005, James et al. 2006).

\section{Acute hypoxia}

Most vascular beds respond to acute hypoxia with more or less severe vasodilation. This is part of the autoregulatory response that brings more blood (and thus oxygen and nutrients) to tissues whose actual metabolic needs exceed current rate of perfusion. Postnatally, the only exception to this rule is the lung, where hypoxia acts as a potent vasoconstrictor stimulus. This hypoxic pulmonary vasoconstriction helps to divert blood flow from poorly ventilated towards better oxygenated lung areas and thus maintains ventilation/perfusion ratio and blood oxygenation.

The first author to suggest that a similar mechanism would make sense also in the placenta was R. Howard in 1987. He hypothesized that "fetoplacental vascular resistance is controlled locally by a reversible hypoxic fetoplacental vasoconstriction (HFPV) in response to reduced local maternoplacental oxygen delivery" (Howard 1987). This idea was partly based on a study showing that reductions in maternal perfusion of the uterus decrease fetal perfusion of the placenta (Stock et al. 1980) and on the finding that maternal and fetal flow correlate (Power et al. 1981). Howard's group soon published an experimental study on perfused human cotyledon showing that, indeed, reduction of partial pressure of oxygen of the perfusate of the maternal lacunas resulted in reversible and reproducible vasoconstriction of the fetoplacental vascular bed (Howard et al. 1987). It is somewhat surprising that even though they immediately recognized the potential of HFPV to "contribute to poor fetal prognosis in preeclampsia" and this view was later widely accepted (Myatt 1992, Poston et al. 1995, Brodsky and Christou 2004, Reynolds et al. 2006) - only exceptional studies mentioning HFPV were published during the ensuing decade (Byrne et al. 1997, Challis et al. 2000).

We became interested in the idea of HFPV at the turn of the millennium. We hypothesized that the lack of

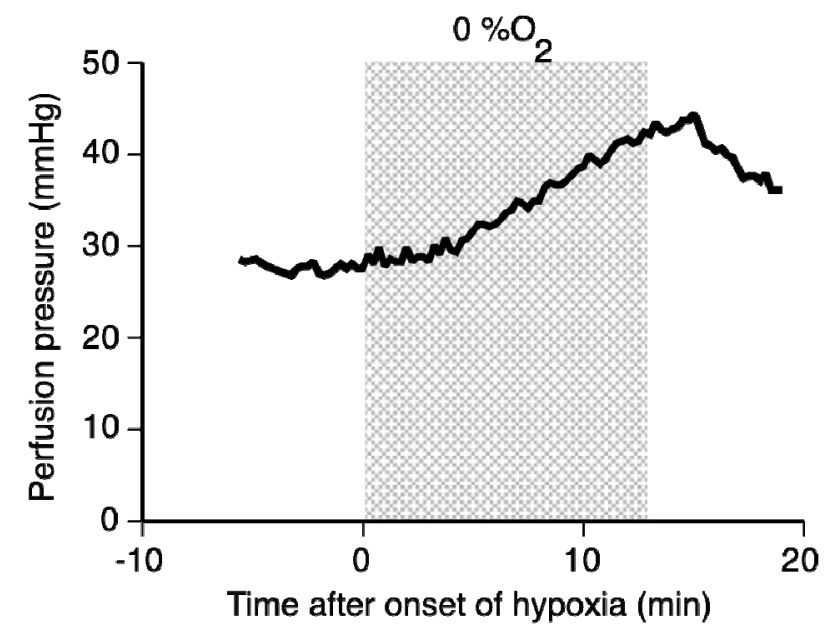

Fig. 1. Acute hypoxic fetoplacental vasoconstriction. Example recording of perfusion pressure in isolated cotyledon of a human placenta during constant flow rate perfusion illustrates vasoconstrictor response to acute hypoxia (shaded area).

interest in HFPV until then was due to the small magnitude of the response in the study of Howard et al. (at constant flow perfusion, pressure rose by $\sim 10 \%$ ). The small magnitude, in turn, according to our reasoning, might have been due to suboptimal experimental conditions, too different from in vivo situation. By optimizing experimental conditions, we were able to show that HFPV can be considerably larger - perfusion pressure increased by at least $20 \%$ (Hampl et al. 2002) (Fig. 1). Thus, HFPV has a potential to be physiologically and pathologically relevant. This was subsequently confirmed in a study that also showed that the magnitude of the vasoconstrictor response is proportional to the degree of hypoxia (Ramasubramanian et al. 2006). The response appears to be localized predominantly in small resistance vessels, since large ones (isolated in organ baths) either do not respond to hypoxia at all (Hampl et al. 2002) or even dilate (Figueroa et al. 1993). Whether predominantly arteries or veins are involved has not been directly studied, even though there is a study showing that hypoxia potentiates vasoconstrictor responses to a thromboxane analog, U46619, in isolated small chorionic plate arteries but not veins (Wareing et al. 2006b). When hypoxia is extended to 6 hours, narrowing of the lumina of vessels in terminal villi can be observed morphologically (Bachmaier et al. 2007).

In the lungs, there is solid evidence that the mechanism of hypoxic vasoconstriction involves hypoxic inhibition of potassium channels (especially the voltagegated family) in the vascular smooth muscle cell membrane which causes depolarization and that in turn is 
a stimulus for activation of voltage-gated calcium channels. Their opening increases intracellular calcium concentration (this is most likely amplified by calciuminduced calcium release from the sarcoplasmic reticulum) and thus activation of the contractile apparatus (Hampl and Herget 1991, Archer and Michelakis 2002).

As a working hypothesis, we assumed that a similar chain of events might be responsible for HFPV. In isolated human placental vessels we and later others demonstrated that fetoplacental vessels express several types of potassium channels of both the voltage-gated and other families (e.g. calcium-activated potassium channels) (Hampl et al. 2002, Wareing et al. 2006a). In smooth muscle cells freshly isolated from peripheral fetoplacental vessels hypoxia inhibited potassium channels-dependent current (Hampl et al. 2002). And in perfused human cotyledon, inhibitor of voltage-gated group of potassium channels, 4-aminopyridine, mimicked hypoxia by causing vasoconstriction on the fetal side (of a similar magnitude as did hypoxia) and blocked further rise in perfusion pressure in response to a superimposed hypoxic challenge (Hampl et al. 2002). Iberiotoxin, a selective inhibitor of calcium-activated potassium channels, was without effect. Thus, as in the pulmonary vessels, the hypoxic vasoconstrictor response in the fetoplacental vessels involves hypoxic inhibition of potassium channels, specifically those of the voltagegated family. Calcium-dependent potassium channels are not affected by hypoxia. Whether other types of potassium channels also play a role in this mechanism remains to be studied.

To elucidate the role of voltage-gated calcium (L-type, $\mathrm{Ca}_{\mathrm{V}} 1$ family) channels in HFPV, hypoxic responses were compared in isolated perfused human cotyledon before and after addition to the perfusate of a selective L-type channels inhibitor nifedipine (or its solvent DMSO in a control group). Even a very low dose of nifedipine (1 nM) completely wiped-out hypoxic reactivity (Jakoubek et al. 2006). Thus, the L-type channels activation, presumably by depolarization caused by hypoxic inhibition of potassium channels, is essential for HFPV. This does not exclude the possibility that calcium release from the sarcoplasmic reticulum induced by calcium influx via L-type channels partly mediates this effect. Our results do seem, however, to exclude the role of capacitive calcium influx, because that current is carried by TRP channels and they, although present in the placental vessels (Wareing et al. 2006a), are not sensitive to nifedipine.
Vasomotor reactivity in all vascular beds is variably modulated by endothelial diffusible factors, such as nitric oxide or prostanoids, especially prostacyclin. From the limited data we have so far it seems that HFPV is not normally modulated by prostaglandins, inasmuch administration of meclofenamate, a cyclooxygenase inhibitor, affects neither basal fetoplacental vascular tone nor the magnitude of HFPV (Hampl et al. 2002). As for nitric oxide, the available data are somewhat controversial. There is a consensus that nitric oxide helps to keep resting vascular tone in the placenta low, as evidenced by a vasoconstriction elicited by administration of nitric oxide synthase inhibitor, L-NAME (Byrne et al. 1997, Hampl et al. 2002). However, the response to hypoxia was found unchanged by L-NAME in one study (Hampl et al. 2002) and abolished in another (Byrne et al. 1997). Consequently, the two studies differ markedly in their conclusions about the role of nitric oxide in HFPV - one excludes it, the other considers it important. The reason for the discrepancy is currently unknown. We suspect that the reason could be the highly hyperoxic baseline conditions and a high dose of L-NAME (known to have numerous side-effects in addition to nitric oxide synthase inhibition) in the study of Byrne et al. (1997).

\section{Chronic hypoxia}

The effects of chronic hypoxia on fetoplacental vasculature are even less studied than acute HFPV, despite the likelihood that chronic rather than acute hypoxia might be the culprit in important fetal and neonatal pathologies such as IUGR. In the lungs, chronic hypoxia causes pulmonary hypertension that is not a simple prolongation of acute hypoxic vasoconstriction. While vascular wall tension may or may not be elevated, the increased pressure is maintained also by structural remodeling of the vessels and thus is not readily reversible upon reoxygenation (Herget and Hampl 1995).

We hypothesized that in the fetoplacental vessels chronic hypoxia also causes a chronic elevation in vascular resistance (although in contrast to lungs, it would not have to be expressed as hypertension in vivo, since the consequence of the increased resistance in the fetoplacental vessels could be redirection of blood flow away from the placenta, with little increase in fetoplacental blood pressure). In fact, a similar hypothesis was envisaged by Howard in 1987: ,... it is proposed that 
chronic local maternoplacental ischemia ... can induce an irreversible fetoplacental vasoconstriction by a mechanism different from HFPV in order to permanently shut down fetal blood flow to the area(s) affected“ (Howard 1987). Using isolated dually perfused rat placenta we showed that, indeed, vascular resistance (measured as pressure-flow relationship) was increased by about $20 \%$ when measured at the end of hypoxic exposure lasting for the last third of gestation (Jakoubek et al. 2008) (Fig. 2). As the measurements were not performed under hypoxic conditions, it is evident that this increase in resistance is refractory to acute reoxygenation.

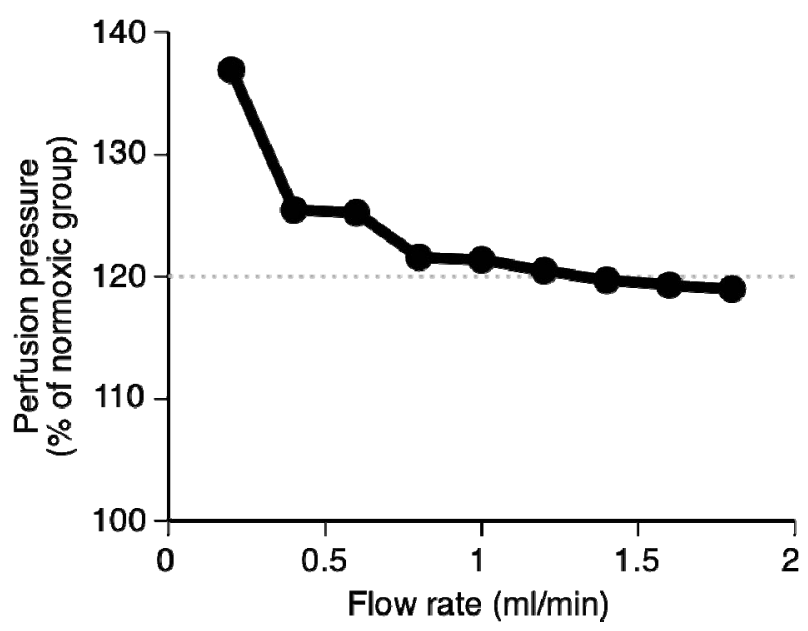

Fig. 2. Chronic hypoxia increases fetoplacental vascular resistance in isolated perfused rat placenta. The graph shows perfusion pressures in the chronically hypoxic group at given levels of perfusion flow rate expressed as \% of the respective values in the normoxic control group.

To assess the involvement of elevated vascular tone in the increased resistance, we measured the effect of a strong vasodilator, sodium nitroprusside. As found previously (Hampl et al. 2002), it had no effect in the control placentas (normal placental vessels have minimal vascular tone, possibly at least in part due to the lack of sympathetic innervation). Somewhat surprisingly, also in the chronically hypoxic placentas sodium nitroprusside did not alleviate the elevated resistance. This implies that the observed elevation in vascular resistance in chronic hypoxia is not caused by increased vascular tone, at least not in a situation when the tissue has been exposed to normoxia for several tens of minutes. This does not exclude the possibility - and indeed likelihood - that in vivo, under persisting hypoxic conditions, the elevation in vascular resistance is even higher due to superimposed hypoxic vasoconstriction. In fact, we found that HFPV is potentiated by chronic hypoxic exposure (Jakoubek et al. 2008).

The elevated vascular resistance refractory to vasodilator treatment implies that morphological remodeling of the vessels is a likely mechanism. While the effects of chronic hypoxia on uteroplacental vessels are relatively well studied (Moore 2003), little is known about fetoplacental vasculature (after it has developed the effects of hypoxia on trophoblast invasion are studied extensively). There are data that chronic hypoxia (of high altitude) stimulates vascularization of villi and increases the villous capillary diameter (Scheffen et al. 1990, Khalid et al. 1997, Espinoza et al. 2001, Zamudio 2003, Tissot van Patot et al. 2004). These changes would be expected to reduce, rather than increase, vascular resistance. However, in principal, morphological changes at the capillary level are less important from the point of view of the overall resistance of the whole vascular bed as compared to changes at the arteriolar level. For example, in a comparable situation of the chronic hypoxic pulmonary hypertension, the total lumen of the resistance lung arterioles is reduced despite increased capillary density (Farber and Loscalzo 2004, McLaughlin and McGoon 2006). There are preliminary results indicating that hypoxia during the last 2 weeks of a 3-week gestation in rats reduces the number of chorionic plate arteries and internal diameter of both chorionic plate and intraplacental arteries (Hampl et al. 2007). In addition, the vascular wall was found to have irregularly distributed thin and thick sections, and the thick ones were significantly thicker in chronically hypoxic as compared to normoxic placentas. These findings may help to explain the elevated fetoplacental vascular resistance in chronic hypoxia.

The mechanisms responsible for the elevated fetoplacental vascular resistance in chronic hypoxia are completely unknown at present. We can only assume that some of the mechanisms known in chronic hypoxic pulmonary hypertension, such as oxidative vascular wall injury from oxygen radicals (Lachmanová et al. 2005) and nitric oxide and its derivatives (Archer et al. 1994, Hampl and Herget 2000, Hampl et al. 2006) leading to collagenous repair (Zaidi et al. 2002, Herget et al. 2003) by activated mast cells (Vajner et al. 2006, Baňasová et al. 2008), serotonin metabolism alterations (Bělohlávková et al. 2001, Dempsie and MacLean 2008) and/or Rho kinase pathway activation (Fagan et al. 2004, Parker et al. 2006), are likely to play significant roles in the placenta as well. 


\section{Conclusions and perspectives}

The long suspected chain of events, in which uteroplacental hypoxia (due to maternal hypoxia or illness) increases fetoplacental vascular resistance and consequently hypoperfusion of the placenta, fetal undernutrition and growth restriction, now has its major steps experimentally proven, described and methodologically accessible for further study. For acute hypoxia, there are even important insights into the mechanisms involved, including hypoxic inhibition of potassium channels in fetoplacental vascular smooth muscle cells, leading to membrane depolarization, voltage-dependent calcium channels activation, calcium influx and thus contractile apparatus activation. For chronic hypoxia, the mechanisms are currently mostly unknown, but do seem to include morphological remodeling of fetoplacental vessels. In addition to the mechanisms, other issues that need further study include the physiological role and effectiveness of HFPV (redirection of blood flow to better oxygenated areas, coordination with the rest of the fetal cardiovascular system) and possible therapeutic intervention in chronic hypoxia.

\section{Conflict of Interest}

There is no conflict of interest.

\section{Acknowledgements}

The experimental work of our group reviewed here was funded by the Grant Agency of the Charles University (\# 82/2004/C and 55/2001/c/2.LF) and Czech Ministry of Education (\# 1M6798582302). We acknowledge an inspiration by the dissertation of V. Jakoubek, although there are no direct quotations.

\section{References}

ARBEILLE P: Fetal arterial Doppler-IUGR and hypoxia. Eur J Obstet Gynecol Reprod Biol 75: 51-53, 1997.

ARCHER S, HAMPL V, MCKENZIE Z, NELSON D, HUANG J, SHULTZ P, WEIR EK: Role of endothelial-derived nitric oxide in normal and hypertensive pulmonary vasculature. Semin Respir Med 15: 179-189, 1994.

ARCHER S, MICHELAKIS E: The mechanism(s) of hypoxic pulmonary vasoconstriction: potassium channels, redox $\mathrm{O}_{2}$ sensors, and controversies. News Physiol Sci 17: 131-137, 2002.

BACHMAIER N, LINNEMANN K, MAY K, WARZOK R, KUNO S, NIEMEYER M, BALK S, FUSCH C: Ultrastructure of human placental tissue after $6 \mathrm{~h}$ of normoxic and hypoxic dual in vitro placental perfusion. Placenta 28: 861-867, 2007.

BAŇASOVÁ A, MAXOVÁ H, HAMPL V, VÍZEK M, POVÝŠILOVÁ V, NOVOTNÁ J, VAJNEROVÁ O, HNILIČKOVÁ O, HERGET J: Prevention of mast cell degranulation by disodium cromoglycate attenuates the development of hypoxic pulmonary hypertension in rats exposed to chronic hypoxia. Respiration 76: 102-107, 2008.

BĚLOHLÁVKOVÁ S, ŠIMÁK J, KOKEŠOVÁ A, HNILIČKOVÁ O, HAMPL V: Fenfluramine-induced pulmonary vasoconstriction: role of serotonin receptors and potassium channels. J Appl Physiol 91: 755-761, 2001.

BRODSKY D, CHRISTOU H: Current concepts in intrauterine growth restriction. J Intens Care Med 19: 307-319, 2004.

BYRNE BM, HOWARD RB, MORROW RJ, WHITELEY KJ, ADAMSON SL: Role of the L-arginine nitric oxide pathway in hypoxic fetoplacental vasoconstriction. Placenta 18: 627-634, 1997.

CHALLIS DE, PFARRER CD, RITCHIE JWK, KOREN G, ADAMSON SL: Glucose metabolism is elevated and vascular resistance and maternofetal transfer is normal in perfused placental cotyledons from severely growthrestricted fetuses. Pediatr Res 47: 309-315, 2000.

DEMPSIE Y, MACLEAN MR: Pulmonary hypertension: therapeutic targets within the serotonin system. $\mathrm{Br} J$ Pharmacol 155: 455-462, 2008.

ESPINOZA J, SEBIRE N, MCAULIFFE F, KRAMPL E, NICOLAIDES K: Placental villus morphology in relation to maternal hypoxia at high altitude. Placenta 22: 606-608, 2001.

FAGAN KA, OKA M, BAUER NR, GEBB SA, IVY DD, MORRIS KG, MCMURTRY IF: Attenuation of acute hypoxic pulmonary vasoconstriction and hypoxic pulmonary hypertension in mice by inhibition of Rho-kinase. Am J Physiol 287: L656-L664, 2004. 
FARBER HW, LOSCALZO J: Pulmonary arterial hypertension. N Engl J Med 351: 1655-1665, 2004.

FIGUEROA R, OMAR HA, TEJANI N, WOLIN MS: Gestational diabetes alters human placental vascular responses to changes in oxygen tension. Am J Obstet Gynecol 168: 1616-1622, 1993.

HAMPL V, HERGET J: Possible mechanisms of oxygen sensing in the pulmonary circulation. Physiol Res 40: 463470, 1991.

HAMPL V, HERGET J: Role of nitric oxide in the pathogenesis of chronic pulmonary hypertension. Physiol Rev 80: 1337-1372, 2000.

HAMPL V, BÍBOVÁ J, STRAŇÁK Z, WU X, MICHELAKIS ED, HASHIMOTO K, ARCHER SL: Hypoxic fetoplacental vasoconstriction in humans is mediated by potassium channel inhibition. Am J Physiol 283: H2440-H2449, 2002.

HAMPL V, BÍBOVÁ J, BAŇASOVÁ A, UHLÍK J, MIKOVÁ D, HNILIČKOVÁ O, LACHMANOVÁ V, HERGET J: Pulmonary vascular iNOS induction participates in the onset of chronic hypoxic pulmonary hypertension. Am J Physiol 290: L11-L20, 2006.

HAMPL V, JAKOUBEK V, KLESCOVÁ A: Oxygen sensing in fetoplacental vessels (abstract). Acta Physiol 191: 20 (SF12-54), 2007.

HERGET J, HAMPL V: Pulmonary circulation. In: Biomechanics of the Cardiovascular System. BB ŠRÁMEK, J VALENTA, F KLIMEŠ (eds), Czech Technical University Press, Prague, 1995, pp 327-336.

HERGET J, NOVOTNÁ J, BÍBOVÁ J, POVÝŠILOVÁ V, VAŇKOVÁ M, HAMPL V: Metalloproteinase inhibition by Batimastat attenuates pulmonary hypertension in chronically hypoxic rats. Am J Physiol 285: L199-L208, 2003.

HOWARD R: Control of human placental blood flow. Med Hypotheses 23: 51-58, 1987.

HOWARD RB, HOSOKAWA T, MAGUIRE H: Hypoxia-induced fetoplacental vasoconstriction in perfused human placental cotyledons. Am J Obstet Gynecol 157: 1261-1266, 1987.

JAKOUBEK V, BÍBOVÁ J, HAMPL V: Voltage-gated calcium channels mediate hypoxic vasoconstriction in the human placenta. Placenta 27: 1030-1033, 2006.

JAKOUBEK V, BÍBOVÁ J, VENCLÍKOVÁ K, TRNKOVÁ A, HERGET J, HAMPL V: Chronic hypoxia increases fetoplacental vascular resistance and vasoconstrictor reactivity in the rat. Am J Physiol 294: H1638-H1644, 2008.

JAMES JL, STONE PR, CHAMLEY LW: The regulation of trophoblast differentiation by oxygen in the first trimester of pregnancy. Hum Reprod Update 12: 137-144, 2006.

KHALID M, ALI M, ALI K: Full-term birth weight and placental morphology at high and low altitude. Int J Gynaecol Obstet 57: 259-265, 1997.

LACHMANOVÁ V, HNILIČKOVÁ O, POVÝŠILOVÁ V, HAMPL V, HERGET J: N-acetylcysteine inhibits hypoxic pulmonary hypertension most effectively in the initial phase of chronic hypoxia. Life Sci 77: 175-182, 2005.

MCLAUGHLIN VV, MCGOON MD: Pulmonary arterial hypertension. Circulation 114: 1417-1431, 2006.

MOORE LG: Fetal growth restriction and maternal oxygen transport during high altitude pregnancy. High Alt Med Biol 4: 141-156, 2003.

MYATT L: Control of vascular resistance in the human placenta. Placenta 13: 329-341, 1992.

OSOL G, MANDALA M: Maternal uterine vascular remodeling during pregnancy. Physiology 24: 58-71, 2009.

PARKER TA, ROE G, GROVER TR, ABMAN SH: Rho kinase activation maintains high pulmonary vascular resistance in the ovine fetal lung. Am J Physiol 291: L976-L982, 2006.

PAVEK P, STAUD F, FENDRICH Z, SKLENAROVA H, LIBRA A, NOVOTNA M, KOPECKY M, NOBILIS M, SEMECKY V: Examination of the functional activity of P-glycoprotein in the rat placental barrier using rhodamine 123. J Pharmacol Exp Ther 305: 1239-1250, 2003.

POSTON L, MCCARTHY AL, RITTER JM: Control of vascular resistance in the maternal and feto-placental arterial beds. Pharmacol Ther 65: 215-239, 1995.

POWER GG, DALE PS, NELSON PS: Distribution of maternal and fetal blood flow within cotyledons of the sheep placenta. Am J Physiol 241: H486-H496, 1981. 
RAMASUBRAMANIAN R, JOHNSON RF, DOWNING JW, MINZTER BH, PASCHALL RL: Hypoxemic fetoplacental vasoconstriction: a graduated response to reduced oxygen conditions in the human placenta. Anesth Analg 103: 439-442, 2006.

REYNOLDS LP, CATON JS, REDMER DA, GRAZUL-BILSKA AT, VONNAHME KA, BOROWICZ PP, LUTHER JS, WALLACE JM, WU G, SPENCER TE: Evidence for altered placental blood flow and vascularity in compromised pregnancies. J Physiol Lond 572: 51-58, 2006.

SCHEFFEN I, KAUFMANN P, PHILIPPENS L, LEISER R, GEISEN C, MOTTAGHY K: Alterations of the fetal capillary bed in the guinea pig placenta following long-term hypoxia. Adv Exp Med Biol 277: 779-790, 1990.

STAUD F, VACKOVA Z, POSPECHOVA K, PAVEK P, CECKOVA M, LIBRA A, CYGALOVA L, NACHTIGAL P, FENDRICH Z: Expression and transport activity of breast cancer resistance protein (Bcrp/Abcg2) in dually perfused rat placenta and HRP-1 cell line. J Pharmacol Exp Ther 319: 53-62, 2006.

STOCK M, ANDERSON DF, PHERNETTON TM, MCLAUGHLIN MK, RANKIN JHG: Vascular response of the fetal placenta to local occlusion of the maternal placental vasculature. J Dev Physiol 2: 339-346, 1980.

STRASZEWSKI-CHAVEZ SL, ABRAHAMS VM, MOR G: The role of apoptosis in the regulation of trophoblast survival and differentiation during pregnancy. Endocr Rev 26: 877-897, 2005.

ŠTULC J, ŠTULCOVÁ B, ŠVIHOVEC J: Transport of calcium across the dually perfused placenta of the rat. $J$ Physiol Lond 420: 295-311, 1990.

TISSOT VAN PATOT MC, BENDRICK-PEART J, BECKEY VE, SERKOVA N, ZWERDLINGER L: Greater vascularity, lowered HIF-1/DNA binding, and elevated GSH as markers of adaptation to in vivo chronic hypoxia. Am J Physiol 287: L525-L532, 2004.

VAJNER L, VYTÁŠEK R, LACHMANNOVÁ V, UHLÍK J, KONRÁDOVÁ V, NOVOTNÁ J, HAMPL V, HERGET $\mathrm{J}$ : Acute and chronic hypoxia as well as 7-day recovery from chronic hypoxia affects the distribution of pulmonary mast cells and their MMP-13 expression in rats. Int $J$ Exp Pathol 87: 383-391, 2006.

WAREING M, BAI X, SEGHIER F, TURNER CM, GREENWOOD SL, BAKER PN, TAGGART MJ, FYFE GK: Expression and function of potassium channels in the human placental vasculature. Am J Physiol 291: R437R446, 2006a.

WAREING M, GREENWOOD SL, BAKER PN: Reactivity of human placental chorionic plate vessels is modified by level of oxygenation: differences between arteries and veins. Placenta 27: 42-48, 2006b.

ZAIDI SHE, YOU X-M, CIURA S, HUSAIN M, RABINOVITCH M: Overexpression of the serine elastase inhibitor elafin protects transgenic mice from hypoxic pulmonary hypertension. Circulation 105: 516-521, 2002.

ZAMUDIO S: The placenta at high altitude. High Alt Med Biol 4: 171-191, 2003. 